\title{
PENGARUH KEPRIBADIAN, SELF EFFICACY DAN LOCUS OF CONTROL TERHADAP KINERJA KARYAWAN
}

\author{
*Edi Siregar, Richa Natalia Anggina \\ *Dosen Tetap PPS Universiats SatyaNegara Indonesia J1.Arteri Pondok Indah No.11 Jakarta. \\ edisiregarusni@gmail.com
}

ABSTRACT

This study aims to determine whether there is a significant effect of personality, selfefficacy and locus of control on employee performance. Data collected from distributing questionnaires to 85 respondents who are part of PT. Pegadaian (Persero) Kebayoran Lama Branch Office. The research methodology used is quantitative processing of questionnaire data and observations with multiple linear regression analysis methods. Based on the results of the study, it is known that simultaneously personality, self-efficacy and locus of control have a significant influence on employee performance. Personality and self-efficacy partially have a significant effect on employee performance. Locus of control partially has no effect on employee performance. The percentage of the influence of personality, self-efficacy and locus of control on employee performance is $18.9 \%$, the remaining $81.1 \%$ is influenced by other variables not included in this study

Keywords: personality, self-efficacy, locus of control, employee performance.

\section{PENDAHULUAN}

PT. Pegadaian (Persero) adalah salah satu badan usaha milik negara (BUMN) yang resmi mempunyai izin untuk melaksanakan kegiatan lembaga keuangan yang bergerak pada tiga lini bisnis, yaitu: pembiayaan, emas dan aneka jasa. Pelaksanaan keuangan ini berupa pembiayaan dalam bentuk penyaluran dana ke masyarakat atas dasar hukum gadai. Dengan inovasi yang dilakukan secara berkesinambungan dalam memberikan kemudahan kepada pelanggan. Dalam era globalisasi saat ini, perusahaan didorong untuk menjadi organisasi yang efektif dan efesien. Hal ini sangat dibutuhkan agar perusahaan dapat bersaing dan memiliki keunggulan yang lebih, sehingga dapat bertahan dalam persaingan yang ketat terutama dalam pengelolaan sumber daya manusia (SDM).

SDM merupakan modal terpenting perusahaan karena perannya sebagai subyek pelaksana kebijakan dan kegiatan operasional perusahaan. Sumber daya yang dimiliki oleh perusahaan seperti modal, metode dan mesin tidak bisa memberikan hasil yang optimum apabila tidak didukung oleh SDM yang mempunyai kinerja optimal. Berdasarkan survei awal yang dilakukan peneliti, diperoleh data yang menunjukkan tingkat penurunan terlihat pada tabel berikut:

\section{Laporan Pinjaman Dana PT. Pegadaian (Persero)}

\begin{tabular}{|l|l|l|}
\hline No. & Tahun & Jumlah Pinjaman \\
\hline 1 & 2017 & Rp. 158.402.368.343 \\
\hline 2 & 2018 & Rp. 158.419.924.520 \\
\hline 3 & 2019 & Rp. 154.947.631.423 \\
\hline
\end{tabular}


Berdasarkan data di atas dapat dilihat pada tahun 2017 total pinjaman sebesar Rp.158.402.368.343 dan mengalami peningkatan pada tahun 2018 sebesar Rp.158.419.924.520 namun pada tahun 2019 mengalami penurunan sebesar Rp.154.947.631.423. Berikut adalah jumlah nasabah pada PT. Pegadaian selama 3 tahun terakhir yang mengalami penurunan secara bertahap:

\section{Data Jumlah Nasabah di PT. Pegadaian (Persero)}

\begin{tabular}{|l|l|l|}
\hline No. & Tahun & Jumlah Per-Tahun \\
\hline 1. & 2017 & 15.003 Nasabah \\
\hline 2. & 2018 & 10.338 Nasabah \\
\hline 3. & 2019 & 10.126 Nasabah \\
\hline
\end{tabular}

Dari tabel tersebut terlihat bahwa dalam setiap tahun mengalami penurunan yang cukup besar secara bertahap. Mulai dari tahun 2017-2019 PT. Pegadaian mengaami penurunan jumlah nasabah yang cukup banyak. Pada tahun 2017 total nasabah sebanyak 15.003 di tahun 2018 total nasabah sebanyak 10.338 dan pada tahun 2019 kian menurun dengan jumlah nasabah sebanyak 10.126.

Berdasarkan hasil kuesioner pra survei bahwa faktor penyebab kenerja karyawan mengalami penurunan adalah masalah kepribadian, self efficacy dan locus of control. Penyebab terjadinya penurunan kinerja karyawan menurut hasil pengamatan peneliti dapat dipengaruhi oleh karakteristik individual yang bersifat melekat pada diri seseorang yang dapat berubah-ubah atau stabil sepanjang waktu dan hal ini juga dapat terlihat dari cara seseorang beradapatasi dengan antar karyawan.

Dalam beradaptasi tiap individu memiliki cara yang berbeda, contohnya adalah self efficacy dan locus of control yang terbentuk karena adanya faktor pengalaman dan pembelajaran. Self efficacy adalah bentuk perasaan kepercayaan diri dalam menyelesaikan suatu tugas. Self efficacy adalah keyakinan seseorang mengenai peluangnya untuk berhasil mencapai tugas tertentu. Seseorang dengan self efficacy yang tinggi akan mencapai suatu kinerja yang lebih baik. Oleh karena seseorang tersebut memiliki motivasi yang kuat, tujuan yang jelas, emosi yang stabil dan kemampuan untuk memberikan kinerja atas aktivitas atau perilaku dengan baik.

Locus of control merupakan salah satu karakter seseorang, setiap orang memiliki karakter yang berbeda. Locus of control menunjukkan tingkat dimana individu percaya bahwa perilaku mempengaruhi yang terjadi pada mereka. Locus of control itu sendiri dibedakan menjadi dua yaitu: Locus of control internal dimana individu percaya bahwa dirinya mengendalikan peristiwa dan konsekuensi yang mempengaruhi kehidupan mereka. Locus of control eksternal dimana individu percaya bahwa prestasi mereka merupakan hasil dari keadaan diluar kendali mereka. Hal tersebut mampu mempengaruhi tingkat kinerja karyawan yang dapat mengganggu kesuksesan bisnis perusahaan baik dalam jangka pendek maupun dalam jangka panjang.

Penelitian disini bertujuan untuk menguji apakah perilaku seseorang ketika dihadapkan oleh situasi dilematis dalam pekerjaannya dan karakterisitk psikologi yang berbeda yang diwakili oleh kepribadian, self efficacy dan locus of control akan memiliki efek terhadap kinerja karyawan ataupun tidak sama sekali. Dari latar belakang yang telah dijelaskan di atas, maka judul penelitian: Pengaruh Kepribadian, Self Efficacy dan Locus of Control Terhadap Kinerja Karyawan. berikut:

Berdasarkan fenomena masalah di atas, permasalahan yang dirumuskan peneliti sebagai 
1) Apakah kepribadian, self efficacy dan locus of control secara simultan berpengaruh terhadap kinerja karyawan PT. Pegadaian (Persero) Kantor Cabang Kebayoran Lama?

2) Apakah kepribadian secara parsial berpengaruh terhadap kinerja karyawan pada PT. Pegadaian (Persero) Kantor Cabang Kebayoran Lama?

3) Apakah self efficacy secara parsial berpengaruh terhadap kinerja karyawan pada PT. Pegadaian (Persero) Kantor Cabang Kebayoran Lama?

4) Apakah locus of control secara parsial berpengaruh terhadap kinerja karyawan pada PT. Pegadaian (Persero) Kantor Cabang Kebayoran Lama?

\section{LANDASAN TEORI}

\section{A. Kinerja}

Menurut Mangkunegara (2015:67) menyatakan bahwa kinerja adalah hasil kerja secara kualitas dan kuantitas yang di capai oleh seorang pegawai dalam melaksanakan tugasnya sesuai dengan tanggung jawab yang diberikan kepadanya. Berdasarkan definisi tersebut menjelaskan bahwa kinerja karyawan adalah hasil kerja seorang pegawai sesuai dengan kemampuan yang dimiliki seseorang dalam melaksanakan tugasnya sesuai dengan tanggung jawab yang diberikan.
1. Dimensi dan Indikator
a. Kuantitas kerja
1).Pekerjaan yang dihasilkan
2) Kerajinan
3) Penyelesaian pekerjaan
b. Kualitas kerja
1) Melakukan pekerjaan sesuai standar kerja
2) Ketelitian
3) Kerapian dalam bekerja

\section{B. Kepribadian}

Muin, Nurseha (2017:21), menyatakan bahwa kepribadian itu tidak dapat dipisahkan dari diri seseorang. Sikap seseorang akan lebih jelas diterangkan dengan tingkah laku dan dalam hubungannya dengan situasinya. Berdasarkan definisi tersebut menjelaskan bahwa kepribadian adalah jati diri dari seseorang yang dapat dilihat dari tingkah laku dan caranya mengatasi suatu kondisi.

\section{Dimensi dan Indikator}

a. Extraversi (Extraversion)

b. Suka bergaul

1) Banyak komunikasi

2) Tegas

c. Mudah akur atau mudah bersepakat (Agreeableness)

1) Baik

2) Kooperatif

3) Dapat dipercaya

d. Sifat berhati-hati (Conscientiousness)

1) Bertanggung jawab

2) Tekun

3) Disiplin

e. Stabilitas emosi (Emotional Stability)

1) Tenang (Respon Positif)

2) Kegelisahan

3) Aman

f. Terbuka terhadap hal-hal baru (Opennes to Experience) 
1) Imajinatif

2) Sensitif

3) Cerdas

\section{Self Efficacy}

Flora Puspitaningsih (2016:76), menyatakan bahwa self efficacy merupakan keyakinan individu atas kemampuan mengatur dan melakukan serangkaian kegiatan yang menuntut suatu pencapaian atau prestasi. Berdasarkan definisi tersebut menjelaskan bahwa self efficacy adalah keyakinan dalam diri seseorang dalam mengelola suatu kegiatan dengan kemampuan yang dimilikinya untuk suatu penncapaian.

\section{Dimensi dan Indikator}

\section{a. Past Performance}

1) Tugas yang menantang

2) Pelatihan

3) Kepemimpinan yang mendukung

b. Vicarious Experience

1) Kesuksesan rekan kerja.

2) Kesuksesan perusahaan

c. Verbal Persuasion

1) Hubungan atasan dengan pegawai.

2) Peran pemimpin.

d. Emotional Cues

1) Keyakinan akan kemampuan mencapai tujuan.

\section{Locus of Control}

Menurut Robbins and Judge (2015:120) mendefinisikan locus of ontrol sebagai "tingkat dimana individu yakin bahwa mereka adalah penentu nasib mereka sendiri". Berdasarkan definisi tersebut menjelaskan bahwa locus of control adalah keyakinan akan diri sendiri dalam menentukan suatu keputusan yang akan dilakukan tanpa campur tangan orang lain.

\section{Dimensi dan Indikator}

a. Internal Locus of control

1) Suka bekerja keras

2) Memiliki inisiatif yang tinggi

3) Selalu berusaha menemukan pemecahan masalah

4) Berpikir selektif

5) Mempunyai presepsi bahwa usaha harus dilakukan jika ingin berhasil

b. Eksternal Locus of control

1) Kurang berinisiatif

2) Mempunyai presepsi bahwa ada hubungan antara usaha dan kesuksesan

3) Kurang suka dalam berusaha

\section{Kerangka Pemikiran Teoritis}

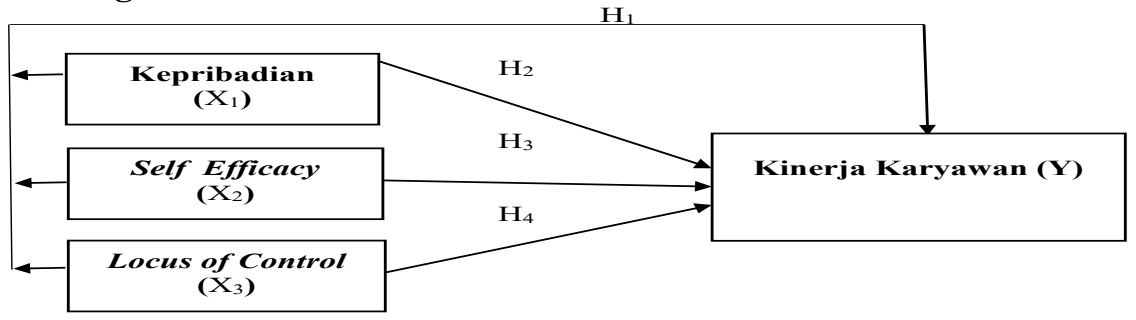




\section{METODOLOGI PENELITIAN}

Populasi dalam penelitian ini adalah karyawan PT. Pegadaian (Persero) Kantor Cabang Kebayoran yang memiliki populasi sebesar 85 Karyawan. Dalam penelitian ini penulis menghitung ukuran sampel menggunakan metode sensus yaitu seluruh jumlah populasi dijadikan responden penelitian.

\section{A. Analisis Hasil dan Pembahasan}

1. Uji Kelayakan Instrument

a. Uji Validitas

Uji validitas bertujuan untuk mengetahui apakah ada pertanyaan atau pernyataan pada kuesioner yang harus diganti karena dianggap tidak valid.

Menilai kevalidan masing-masing butir pertanyaan atau pernyataan dapat dilihat dari $\mathrm{r}$ hitung, dikatakan valid jika nilai $\mathrm{r}_{\text {hitung }}>\mathrm{r}_{\text {tabel. }}$. Nilai $\mathrm{r}_{\text {tabel }}$ diperoleh melalui $\mathrm{df}$ (degree of freedom $)=\mathrm{n}-2(\mathbf{3 0 - 2}=\mathbf{2 8})$ maka nilai $\mathrm{r}_{\text {tabel }} 0,361$. Dasar pengambilan keputusan:

1) Jika $r_{\text {hitung }}>r_{\text {tabel }}$, maka butir pertanyaan atau variable valid.

2) Jika $\mathrm{r}_{\text {hitung }}<\mathrm{r}_{\text {tabel, }}$, maka butir pertanyaan atau variable tidak valid.

b. Uji Realibilitas

Suatu kuesioner dapat dikatakan reliabel atau handal jika jawaban seseorang terhadap pertanyaan atau pernyataan adalah konsisten atau stabil dari waktu ke waktu (Ghozali,2013:47). Maka semakin tinggi tingkat reliabilitas suatu alat pengukur maka semakin stabil pula alat pengukur tersebut.

Dalam SPSS diberikan fasilitas untuk mengukur reliabilitas dengan uji statistik Cronbach Alpha $(\alpha)$, suatu konstruk atau variabel dikatakan reliabel jika memberikan nilai Conbarch Alpha $>0,70$ (Ghozali,2013:48).

Dasar pengambilan keputusan:

1) Alpha $>\mathrm{r}$ tabel $=$ reliable

2) Alpha $<\mathrm{r}$ tabel $=$ tidak reliable

\section{Uji Normalitas Data}

Apabila nilai signifikasi Kolmogrov-Smirnov adalah lebih kecil dari 0,05 maka $\mathrm{H}_{\mathrm{a}}$ diterima, sehingga data residual tidak berstribusi normal. Sebaliknya apabila nilai signifikasi Kolmogrov-Smirnov adalah lebih besar dari 0,05 maka $\mathrm{H}_{\mathrm{a}}$ ditolak, sehingga dari residual berdistribusi normal.

Berdasarkan hasil uji normalitas diatas, diketahui bahwa nilai signifikasi ke empat variabel tersebut lebih besar dari 0.05, sehingga dapat disimpulkan bahwa keempat data yang telah dilakukan pengujian berdistribusi normal.

3. Uji Analisis Statistik Deskriptif

a. Uji Deskriptif

Analisis Deskriptif bertujuan untuk menyajikan gambaran umum mengenai penyebaran kuesioner atau distribusi data.

\section{b. Uji Multikoliniearitas}

Uji multikoliniearitas bertujuan untuk menguji apakah dalam model regresi ditemukan adanya korelasi antara variabel independent. Jika ada korelasi yang tinggi antara variabel independent tersebut, maka hubungan antara variabel independent dengan variabel dependent akan terganggu. Model regresi yang baik seharusnya tidak terjadi multikoliniearitas. Nilai tolerance dan VIF (Variance Inflation Factor). Untuk bebas dari masalah multikolinieritas nilai tolerance harus $>0.10$ dan nilai $\mathrm{VIF}<10$. Nilai tolerance untuk variabel Kepribadian $\left(\mathrm{X}_{1}\right)$ sebesar 0,749. Self Efficacy $\left(\mathrm{X}_{2}\right)$ sebesar 0,813. Locus of Control $\left(\mathrm{X}_{3}\right)$ adalah sebesar 0,892. Sedangkan VIF (Variance Inflation Factor) untuk variabel Kepribadian $\left(\mathrm{X}_{1}\right)$ sebesar 1,336. Self Efficacy $\left(\mathrm{X}_{2}\right)$ sebesar 1,231. Locus of Control $\left(\mathrm{X}_{3}\right)$ sebesar 1,121. Maka dapat dinyatakan bahwa tidak terjadi multikolinieritas antar variabel bebas, karena nilai tolerance untuk masing-masing variabel adalah lebih 
besar dari 0,10 dan nilai VIF (Variance Inflation Factor) untuk masing-masing variabel lebih kecil dari 10.

\section{c. Uji Heteroskedastisitas}

Uji Heteroskedastisitas bertujuan untuk menguji apakah dalam model regresi terjadi ketidaksamaan variance dari residual satu pengamatan ke pengamatan yang lain. Hasil dari Uji Heteroskedastisitas dalam penelitian ini adalah sebagai berikut: Berdasarkan hasil uji heteroskedastisitas diketahui bahwa titik-titik membentuk pola yang tidak beraturan dan titik-titik menyebar di atas dan di bawah angka 0 pada sumbu Y. Tidak terjadi heteroskedastisitas dalam model regresi.

\section{d. Uji Autokorelasi}

Autokorelasi merupakan korelasi antara anggota observasi yang disusun menurut waktu dan tempat. Model regresi yang baik seharusnya tidak terjadi autokorelasi. Metode pengujian menggunakan uji Durbin Watson (DW test). Dasar pengambilan keputusan pada uji Durbin Watson sebagai berikut:

a. $\quad$ DU $<$ DW $<4$-DU maka Ho diterima, artinya tidak terjadi autokorelasi

b. DW $<$ DL atau DW $>4$-DL maka Ho ditolak, artinya terjadi autokorelasi

c. DL $<$ DW $<$ DU atau 4-DU $<$ DW $<4$-DL, artinya tidak ada kepastian atau kesimpulan yang pasti.

\section{Model Summary}

\begin{tabular}{|l|l|l|l|l|l|}
\hline Model & $R$ & R Square & $\begin{array}{l}\text { Adjusted } \\
\text { R Square }\end{array}$ & $\begin{array}{l}\text { Std. Error of the } \\
\text { Estimate }\end{array}$ & Durbin-Watson \\
\hline 1 & $.467^{\mathrm{a}}$ & .218 & .189 & 4.295 & 2.015 \\
\hline
\end{tabular}

a. Predictors: (Constant), Locus of Control, Self Efficacy, Kepribadian

b. Dependent Variable: Kinerja Karyawan

Penelitian ini menggunakan Uji Durbin Watson (DW test) sebagai analisis data. Dimana nilai DL dan DU diperoleh dengan melihat tabel statistik Durbin Watson pada tingkat signifikansi $\alpha=5 \%, \mathrm{k}=3$ (jumlah variabel bebas yaitu $\mathrm{X}_{1}, \mathrm{X}_{2,}, \mathrm{X}_{3}$ ), kemudian diperoleh nilai $\mathrm{DL}=1,575$ dan nilai $\mathrm{DU}=1,721$ dengan $\mathrm{n}=85$ (jumlah responden), nilai $\mathrm{DW}=$ 2,015 yang diperoleh dari hasil pengolahan data, 4-DL $=2,425$ dan 4-DU $=2,279$. Sehingga nilai DU $<$ DW $<4$-DU $(1,721<2,015<2,279)$ artinya tidak terjadi autokorelasi pada penelitian ini.

\section{e. Uji Korelasi}

Untuk menganalisa korelasi antara variabel

\section{f. Uji regresi Linear Berganda}

Uji analisis regresi linear berganda digunakan untuk mengetahui pengaruh atau hubungan secara linear antara dua atau lebih variabel independen dengan satu variabel dependen.

Coefficients

\begin{tabular}{|c|c|c|c|c|c|c|c|}
\hline \multirow[b]{2}{*}{ Model } & \multicolumn{2}{|c|}{$\begin{array}{l}\text { Unstandardized } \\
\text { Coefficients }\end{array}$} & \multirow{2}{*}{$\begin{array}{l}\text { Standardize } \\
\mathrm{d} \\
\text { Coefficients } \\
\text { Beta }\end{array}$} & \multirow[b]{2}{*}{$\mathrm{t}$} & \multirow[b]{2}{*}{ Sig. } & \multicolumn{2}{|c|}{ Collinearity Statistics } \\
\hline & B & Std. Error & & & & Tolerance & VIF \\
\hline (Constant) & 51.902 & 13.704 & & 3.787 & .000 & & \\
\hline Kepribadian & .137 & .044 & .353 & 3.111 & .003 & .749 & 1.336 \\
\hline Self Efficacy & .168 & .083 & .221 & 2.032 & .045 & .813 & 1.231 \\
\hline Locus of Control & -.179 & .138 & -.135 & -1.302 & .196 & .892 & 1.121 \\
\hline
\end{tabular}

a. Dependent Variable: Kinerja Karyawan 
Berdasarkan tabel diatas dapat diketahui bahwa persamaan regresi:

$\mathrm{Y}=51,902+0,137 \mathrm{X} 1+0,168 \mathrm{X} 2-0,179 \mathrm{X} 3$

Dari hasil analisis dan persamaan regresi linear berganda, dapat diperoleh persamaan regresi sebagai berikut:

a. Nilai konstanta adalah 51,902 yang artinya jika Kepribadian, Self Efficacy, dan Locus of Control terhadap Kinerja Karyawan nilainya 0, maka Kinerja Karyawan akan bernilai sebesar 51,902.

b. Koefisien Regresi Kepribadian $\left(\mathrm{X}_{1}\right)$ bersifat positif sebesar 0,137 yang artinya jika variabel Kepribadian meningkat 1 satuan, maka akan meningkatkan Kinerja Karyawan sebesar 0,137 dengan asumsi variabel lain tetap.

c. Koefisien Regresi Self Efficacy $\left(\mathrm{X}_{2}\right)$ bersifat positif sebesar 0,168 yang artinya jika variabel Self Efficacy meningkat 1 satuan, maka akan meningkatkan Kinerja Karyawan sebesar 0,168 dengan asumsi variabel lain tetap.

d. Koefisien Regresi Locus of Control $\left(\mathrm{X}_{3}\right)$ bersifat negatif sebesar 0,179 yang artinya jika variabel Locus of Control meningkat 1 satuan, maka akan meningkatkan Kinerja Karyawan sebesar 0,179 dengan asumsi variabel lain tetap.

\section{Uji Hipotesis}

a. Uji F

Uji F untuk melihat bagaimanakah pengaruh semua variabel bebas secara bersama-sama terhadap variabel terikat. Uji $\mathrm{F}$ dapat dilakukan dengan membandingkan $\mathrm{F}_{\text {hitung }}$ dengan $\mathrm{Ft}_{\text {tabel}}$, sebagai berikut:

1) Jika $F_{\text {hitung }}>F_{\text {tabel, }}$, (Ho di tolak Ha, diterima) maka model signifikan atau bisa dilihat dalam kolom signifikansi pada Anova (Olahan dengan SPSS).

2) Jika $F_{\text {hitung }}<F_{\text {tabel, }}$ maka model tidak signifikan. Apabila tingkat signifikansi dibawah 0,05 , maka $\mathrm{H}_{\mathrm{o}}$ ditolak.

3) Menentukan $F_{\text {tabel }}$ pada tingkat signifikansi 0,05 dengan df 1 (jumlah variabel-1) atau 4-1 = 3, dan df2 (n-k-1) atau 85-3-1 = 81, maka hasil $\mathbf{F}_{\text {tabel }} \mathbf{2 , 7 1 5}$.

\section{ANOVA $^{\mathrm{a}}$}

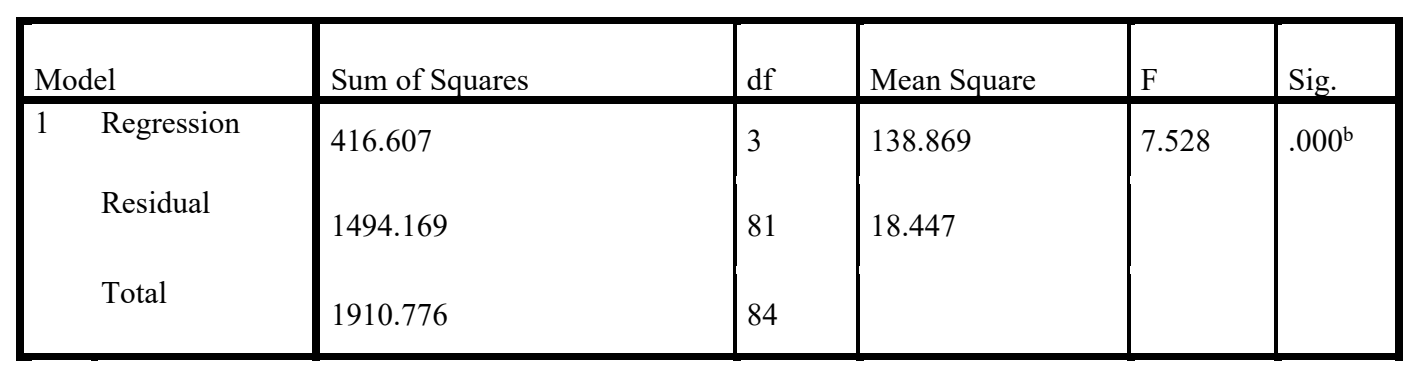

a. Dependent Variable: Kinerja Karyawan

b. Predictors: (Constant), Locus of Control, Self Efficacy, Kepribadian

Melihat tabel di atas menunjukkan bahwa nilai $\mathrm{F}_{\text {hitung }}$ 7,528 $>\mathrm{F}_{\text {tabel }} 2,715$ atau nilai sig $0,000<0,05$ maka $\mathrm{H}_{0}$ ditolak. Dengan demikian dapat disimpulkan bahwa terdapat pengaruh secara signifikan antara kepribadian, $\left(\mathrm{X}_{1}\right)$, self efficacy $\left(\mathrm{X}_{2}\right)$ dan locus of control $\left(\mathrm{X}_{3}\right)$ terhadap kinerja karyawan $(\mathrm{Y})$.

b. Uji t

Uji t pada dasarnya menunjukkan seberapa jauh pengaruh satu variabel independent secara individual dalam menerangkan variabel dependent Pengujian dilakukan dengan menggunakan signifikan level $0,05(\alpha=5 \%)$. Penerimaan atau penolakan hipotesis dilakukan dengan kriteria: 
1) Jika nilai signifikan $>0,05$ maka hipotesis ditolak (koefisien regresi tidak signifikan). Ini berarti secara parsial variabel independent tidak mempunyai pengaruh secara signifikan terhadap variabel dependent.

2) Jika nilai signifikan $\leq 0,05$ maka hipotesis diterima (koefisien regresi signifikan). Ini berarti secara parsial variabel independent tersebut mempunyai pengaruh yang signifikan terhadap variabel dependent.

Nilai $\mathrm{t}$ tabel dihitung dari 2-tailed $\alpha: 0,05 / 2=0,025$, $\mathrm{df}=\mathrm{n}-\mathrm{k}-1=85-3-1=81$, sehingga diperoleh $\boldsymbol{t}_{\text {tabel }} \mathbf{1 , 6 7 1}$.

\begin{tabular}{|c|c|c|c|c|c|}
\hline \multicolumn{6}{|l|}{ Coefficients $^{\mathrm{a}}$} \\
\hline \multirow[b]{2}{*}{ Model } & \multicolumn{2}{|c|}{ Unstandardized Coefficients } & \multirow{2}{*}{$\begin{array}{l}\text { Standardized } \\
\text { Coefficients } \\
\text { Beta }\end{array}$} & \multirow[b]{2}{*}{$\mathrm{t}$} & \multirow[b]{2}{*}{ Sig. } \\
\hline & $\mathrm{B}$ & Std. Error & & & \\
\hline (Constant) & 51.902 & 13.704 & & 3.787 & .000 \\
\hline Kepribadian & .137 & .044 & .353 & 3.111 & .003 \\
\hline Self Efficacy & .168 & .083 & .221 & 2.032 & .045 \\
\hline Locus of Control & -.179 & .138 & -.135 & -1.302 & .196 \\
\hline
\end{tabular}

a. Dependent Variable: Kinerja Karyawan

Melihat tabel coefficients di atas maka dapat dilihat:

1) Variabel Kepribadian $\left(X_{1}\right)$ nilai $t_{\text {hitung }}>t_{\text {tabel }}(3,111>1,671)$ Ho ditolak dan nilai signifikansi $(0,003<0,050)$ maka Ha diterima, yang artinya Kepribadian berpengaruh signifikan terhadap Kinerja Karyawan.

2) Variabel Self Efficacy $\left(\mathrm{X}_{2}\right)$ nilai $\mathrm{t}_{\text {hitung }}<\mathrm{t}_{\text {tabel }}(2,032>1,671)$ Ho ditolak dan nilai siginifikansi $(0,045<0,050)$ maka Ha diterima, yang artinya Self Efficacy berpengaruh signifikan terhadap Kinerja Karyawan..

3) Variabel Locus of Control $\left(\mathrm{X}_{3}\right)$ nilai $\mathrm{t}_{\text {hitung }}<\mathrm{t}_{\text {tabel }}(-1,302<1,671)$ Ho diterima dan nilai signifikansi $(0,196<0,050)$ maka Ha ditolak, yang artinya Locus of Control tidak berpengaruh terhadap Kinerja Karyawan.

\section{c. Uji Koefisien Determinasi $\left(\mathbf{R}^{2}\right)$}

Dalam penelitian ini, analisis koefisien determinasi digunakan untuk mengetahui seberapa besar kemampuan variabel independen menerangkan variasi variabel dependen.

Model Summary ${ }^{\mathrm{b}}$

\begin{tabular}{|l|l|l|l|l|}
\hline Model & $\mathrm{R}$ & R Square & Adjusted R Square & Std. Error of the Estimate \\
\hline 1 & $.467^{\mathrm{a}}$ & .218 & .189 & 4.295 \\
\hline
\end{tabular}

a. Predictors: (Constant), Locus of Control, Self Efficacy, Kepribadian

b. Dependent Variable: Kinerja Karyawan

Melihat tabel summary di atas diketahui nilai adjusted $\mathrm{R}$ square sebesar 0,189 nilai ini dapat diartikan variabel bebas (Kepribadian, Self Efficacy dan Locus of Control) memberikan kontribusi terhadap Kinerja Karyawan (Y) sebesar 18,9\% dan sisanya 81,1\% dipengaruhi oleh faktor lain diluar penelitian. 


\section{PENUTUP.}

\section{A. Kesimpulan}

Berdasarkan hasil penelitian dan pembahasan serta untuk menjawab rumusan masalah penelitian yang ada, maka kesimpulan dalam penelitian ini berdasarkan analisa data yaitu:

1. Secara simultan terdapat pengaruh antara kepribadian $\left(\mathrm{X}_{1}\right)$, self efficacy $\left(\mathrm{X}_{2}\right)$ dan locus of control $\left(\mathrm{X}_{3}\right)$ terhadap kinerja karyawan. Hal ini dibuktikan dengan nilai $\mathrm{F}_{\text {hitung }}>\mathrm{F}_{\text {tabel }}(7.528>$ 2,715) dan signifikansi $0,000<0,050$.

2. Secara parsial variabel bebas kepribadian berpengaruh positif dan signifikan terhadap kinerja karyawan. Hal ini dibuktikan dengan nilai $t_{\text {hitung }}>t_{\text {tabel }}(3.111>1,671)$ dan signifikansi 0,003 $<0,050$.

3. Secara parsial variabel bebas self efficacy berpengaruh positif dan signifikan terhadap kinerja karyawan. Hal ini dibuktikan dengan nilai $t_{\text {hitung }}>t_{\text {tabel }}(2.032>1,671)$ dan signifikansi $0,045<$ 0,050 .

4. Secara parsial variabel bebas locus of control tidak berpengaruh terhadap kinerja karyawan. Hal ini dibuktikan dengan nilai $t_{\text {hitung }}<t_{\text {tabel }}(-1.032<1,671)$ dan signifikansi 0,196 $>0,050$.

\section{B. Saran}

Berdasarkan hasil penelitian dan kesimpulan di atas, maka saran-saran yang dapat penelitian ini berikan berkaitan dengan kinerja karyawan adalah sebagai berikut:

1. Untuk Karyawan

Dalam rangka meningkatkan kinerja karyawan dapat memberikan dukungan untuk pencapaian tujuan perusahaan. Karyawan tetap melakukan evaluasi diri sendiri atas pekerjaan yang dikerjakan.

2. Untuk Perusahaan

Untuk mengendalikan karyawan perlu diberikan sanksi yang tegas bagi karyawan yang melanggar peraturan organisasi yang sudah ditetapkan. Peran kepribadian, self efficacy dan locus of control dalam meningkatkan kinerja karyawan sangat penting. Berikan seminar mengenai kepribadian, self efficacy dan locus of control kepada karyawan agar dapat mengendalikan diri pada saat bekerja untuk memaksimalkan kinerja karyawan. Jika hal tersebut dilakukan dengan baik, maka setiap karyawan bisa bekerja dan mencapai kinerja yang diharapkan.

3. Untuk Mahasiswa dan Peneliti

Berhubung dalam penelitian ini sumbangan pengaruh ketiga variabel yaitu kepribadian, self efficacy dan locus of control terhadap kinerja karyawan hanya sebesar $18,9 \%$ sedangkan sisanya sebesar $81,1 \%$ dipengaruhi oleh variabel lain yang tidak termasuk dalam penelitian ini, maka sebaiknya dalam penelitian mendatang peneliti sarankan untuk mengganti variabel lain yang tidak termasuk dalam penelitian ini.

\section{DAFTAR PUSTAKA}

\section{A. Buku}

Benjamin T., A. R. (2017). Pengembangan Sumber Daya Manusia. Yogyakarta: AHR Publishing.

Dessler, G. (2015). Manajamen Sumber Daya Manusia Edisi:14. Salemba Empat.

Feist, J. d. (2015). Teori Kepribadian : Theories of Personality.Edisi 7.buku 2. Jakarta: Salemba Humanika.

Ghozali, I. (2018). Aplikasi Analisis Multivariate dengan Program IBM SPSS 25. Semarang: Badan Penerbit Universitas Diponegoro.

Imron, M. (2018). Aspek Spiritualitas Dalam Kinerja. Magelang: UNIMMA PRESS.

Kristiyanti, T. (2016). Self-Regulated Learning KOnsep, Implikasi dan Tantangannya Bagi Siswa di Indonesia. Yogyakarta: APPTI.

Luthans, F. (2015). Perilaku Organisasi. (V. Yuwono, Trans.) Yogyakarta: Andi.

Malayu, H. (2017). Manajemen Sumber Daya Manusia.Edisi Revisi. Jakarta: Bumi Aksara. 
Mangkunegara, A. P. (2015). Sumber Daya Manusia Perusahaan. Bandung: Remaja Rosdakarya. Marbawi, A. (2016). Manajamen Sumber daya manusia Teori, prakti dan Penelitian. Surabaya: UNIMA Press.

Mu'ah, M. (2017). Manajemen Sumber Daya Manusia Profesional. Sidoarjo: Zifatama Publishing.

Muin, N. (2016). Deteksi Kepribadian. Jakarta: PT. Bumi Aksara.

Ns. Alfeus Manuntung, S. M. (2018). Terapi Perilaku Kognitif pada Pasien Hipertensi. Malang: Wineka Media.

Prayono, M. (2016). Manajemen Sumber Daya Manusia. Zifatama Publishing,.

Robbins, S. P. (2015). Perilaku Organisasi (Organizational Behavior)" Edisi 15. Buku Terjemahan. Jakarta: Salemba Empat.

Robbins, S. P. (2016). Perilaku Organisasi, Organizational Behavior . Jakarta.: Salemba Empat.

Robert Kreitner, A. K. (2014). Perilaku Organisasi (Organizational Behavior) (Vol. Edisi 9). Jakarta: Salemba Empat.

Sedarmayanti. (2016). Manajamen Sumber Daya Manusia. Bandung: Refika Aditama.

Sugiyono. (2018). Metode Penelitian Kuantitatif, Kualitatif, dan R\&D. Bandung: Alfabeta, CV.

Sunyoto, D. d. (2015). Perilaku Organisasional. Yogyakarta: CAPS.

Syamsuddin, M. A. (2017). Psikologi Pendidikan. Bandung: PT.Rosda Karya Remaja.

Wilson Bangun, S. M. (2017). Manajamen Sumber Daya Manusia. Erlangga.

Wirawan. (2015). Evaluasi Kinerja Sumber Daya Manusia. Teori Aplikasi dan Penelitian. Jakarta: Salemba Empat.

\section{B. Jurnal}

Ary Sinar Deany, S. d. (2016). Pengaruh self esteem, self efficacy, locus of control dan emotional stability pada kinerja pengelola anggaran belanja universitas udayana. E-Jurnal Ekonomi dan Bisnis Universitas Udayana.

Ivan, H. H. (2016). Pengaruh Self Esteem dan Self Efficacy Terhadap Kinerja Karyawan (Studi pada Karyawan PT. Tomo Food Industri, Sumedang). Jurnal Sains Manajemen \& Akuntansi, Volume VIII No. 2.

Puspitaningsih, F. (2016). Pengaruh Pendidikan Kewirausahaan dan Lingkungan keluarga terhadap minat berwirausaha dengan self efficacy sebagai variabel intervening. Jurnal Ekonomi dan Kewirausahaan, Vol.2 no.1, hal 75-88.

Rizkiawati, N. L. (2018). Pengaruh Demografi, Financial Knowledge, Financial Attitude, Locus of Control dan Financial Self-Efficacy Terhadap Financial Management Behavior Masyarakat Surabaya. Jurnal Ilmu Manajemen, 6

Yuda, M. d. (2018). Pengaruh Kepribadian dan Kompetensi terhadap Kinerja Karyawan (Studi Pada Karyawan PT PLN (Persero) Area Pasuruan). Jurnal Administrasi Bisnis (JAB)|Vol. 58 No. 2.

Yusnaena, S. H. (2018). Pengaruh Locus of Control terhadap Kinerja Karyawan Bank Syariah Mandiri KC Padang. Menara Ekonomi ISSN : 2407-8565; E-ISSN: 2579-5295 Volume IV No. 3 . 